JFFI. 2018; 5(1) 258-265

www.jurnal.farmasi.umi.ac.id/index.php/fitofarmakaindonesia

\title{
PROFIL FITOKIMIA DAN PEMERIKSAAN FARMAKOGNOSTIK DAUN ANTING-ANTING (Acalypha indica. L)
}

\author{
Selpida Handayani ${ }^{1}$, Abd. Kadir, Masdiana \\ Laboratorium Bahan Alam, Fakultas Farmasi Universitas Muslim Indonesia \\ 'Selpida.Handayani@umi.ac.id
}

\begin{abstract}
The Anting-anting (Acalypha indica L.) plant of the tribal Euphorbiaceae is one type of plant commonly used as a medicinal plant. The Purpose of This study is to get the morphology data, anatomy, organoleptic, physical determination of powders, powder ekstrabilitas determination, identification of chemical reactions and thin layer chromatography of Anting-anting (Acalypha indica L.) plant. Extraction of Anting-anting (Acalypha indica L.) leaf is using $96 \%$ ethanol by maceration method. Longitudinal slices showed stomata leaf anatomy anisositik type. Fisic desition include 16,36\% decision of dust level 5,16\% decision of unsoluble dust in acid level. Decision of cansentrate level that include 25,16\% consentrate level of water soluble and 26,36\% consentrate level of etanol soluble. The results of this study concluded thet the leaf powder Anting-anting (Acalypha indica L.) is positive for flavanoid, alkaloid, steroid, saponin and aleuron.
\end{abstract}

Keywords: Anting-anting, Acalypha indica, Farmakognostic examination

\section{PENDAhuluan}

Indonesia merupakan salah satu Negara dengan kekayaan hayati terbesar di dunia yang memiliki lebih dari 30.000 spesies tanaman tingkat tinggi. Hingga saat ini, tercatat 7000 spesies tanaman telah diketahui khasiatnya, namun kurang dari 300 tanaman yang digunakan sebagai bahan baku industri farmasi secara regular (Saifuddin dkk, 2011). Belakangan ini banyak bermunculan stigma negatif dimasyarakat terhadap obat-obatan yang terbuat dari bahan-bahan kimia. Salah satunya adalah efek samping yang di hasilkan dari obat-obatan sintesis tersebut baik itu jangka pendek maupun jangka panjang. Sehingga terjadi disorientasi pemahaman dikalangan masyarakat yang mencoba beralih kepengobatan yang lebih alami dan natural. Banyaknya produk-produk herbal saat ini memicu meningkatnya peranan pemanfaatan berbagai macam tanaman-tanaman serta tumbuh-tumbuhan, dan juga dari hewan yang diformulasikan dalam bentuk herbal. Tumbuhan Anting-anting (Acalypha indica. L) suku Euphorbiaceae merupakan salah satu jenis tumbuhan yang biasa digunakan sebagai obat. Tumbuhan ini memiliki rasa yang pahit. Pada akar, batang, dan daun yang mengandung saponin dan tanin. Batang juga mengandung flavanoid dan daunnya mengandung minyak atsiri (Dalimartha, 2000). Berdasarkan pengalaman empiris Antinganting (Acalypha indica. L) bermanfaat untuk antibiotik, antiradang, peluruh seni, astringent, menghentikan pendarahan, dan memberikan rasa sejuk (Ismawan, 2008).

\section{METODE PENELITIAN \\ A. Bahan}

Air suling, Asam klorida $\mathrm{P}$, Asam sulfat $\mathrm{P}$, Dietil eter, Dragendroff, Etanol 96\% P, Flouroglusin LP, Fehling A dan Fehling B, Iodine 0,1 N, Kalium hidroksida $10 \%$, Kertas saring (whatman), Kloralhidrat LP, Kloroform P, Larutan Bauchardat, Larutan Besi (III) Klorida, Larutan Brom, Larutan Lieberman bauchardat, Larutan formalin 1\%, Larutan Liberman, Larutan Luff, Larutan Mayer, Larutan Molish, Metanol, Natrium Hidroksida P, tumbuhan Anting-anting (Acalypha indica.L).

\section{B. Alat}

Cawan porselin, Eksikator, Erlenmeyer $\left(\right.$ pyrex $\left.^{\circledR}\right)$, Gelas pialam $\left(\right.$ pyrex $\left.^{\circledR}\right)$, Gelas ukur $\left(\right.$ pyrex $\left.^{\circledR}\right)$, Lampu UV 254 nm dan 366 nm, Mikroskop, Oven listrik, Penangas air, Seperangkat alat kromatografi lapis tipis, timbangan analitik, tanur.

\section{Prosedur Kerja \\ 1. Pengambilan Sampel}

Sampel yang digunakan dalam penelitian adalah akar, batang, dan daun tumbuhan Antinganting (Acalypha indica.L). Sampel yang digunakan berasal dari Kota Makassar. 


\section{Pengolahan Sampel}

Sampel yang telah diambil, kemudian dicuci bersih dari kotoran-kotoran yang melekat, dengan menggunakan air yang mengalir. Untuk ekstraksi dan serbuk, sampel yang digunakan adalah daun. Daun Anting-anting (Acalypha indica.L) dibersihkan dari kotoran-kotoran yang melekat menggunakan air yang mengalir lalu dikeringkan dengan cara diangin-anginkan. Setelah kering lalu dipotong menjadi potongan-potongan kecil, dan siap untuk diserbuk dan diekstraksi.

\section{Pemeriksaan Farmakognostik}

a. Pemeriksaan morfologi tumbuhan Antinganting (Acalypha indica. $\mathrm{L}$ )

Pemeriksaan morfologi tumbuhan dilakukan dengan mengamati bentuk fisik dari akar, batang, dan daun dari sampel, kemudian dilakukan pengambilan gambar.

\section{b. Pemeriksaan anatomi tumbuhan Anting- anting (Acalypha indica. $\mathrm{L}$ )}

Pemeriksaan dilakukan dengan mengamati bentuk sel dan jaringan tumbuhan pada bagian penampang melintang dan membujur dari akar, batang, dan daun secara mikroskopik. Caranya yaitu dengan mengiris setipis mungkin bagian dari tumbuhan yang akan diperiksa dengan menggunakan pisau silet, kemudian diletakan diatas kaca objek lalu ditetesi dengan kloralhidrat LP, kemudian difiksasi dan ditutup dengan gelas penutup, letakkan preparat yang akan diperiksa diatas meja benda mikroskop dan diamati dan dilakukan pengambilan gambar.

\section{c. Pemeriksaan organoleptik tumbuhan Anting- anting (Acalypha indica.L)}

Pemeriksaan organoleptik dilakukan dengan menggunakan panca indra mengamati warna, bentuk, bau dan rasa dari bagian tumbuhan yang masih segar meliputi akar, batang, dan daun dari tumbuhan Anting-anting (Acalypha indica. L).

\section{Pemeriksaan Tetapan Fisis Serbuk a. Penetapan kadar abu total}

Sebanyak 3 gram serbuk daun Anting-anting (Acalypha indica.L) ditimbang dalam cawan porselin yang telah dikonstankan, kemudian dipijarkan dalam tanur secara perlahan-lahan sehingga arang habis, didinginkan dalam eksikator dan ditimbang hingga bobot tetap atau konstan. Percobaan dilakukan sebanyak 3 kali. Kadar abu dihitung terhadap bahan yang telah dikeringkan diudara.

\section{b. Penetapan kadar abu yang tidak larut dalam asam}

Abu yang telah diperoleh dari penetapan kadar abu total, didihkan dengan $25 \mathrm{ml} \mathrm{HCl}$ selama 5 menit. Kemudian dikumpulkan bagian yang tidak larut dalam asam, dan disaring melalui kertas saring bebas abu. Lalu dicuci dengan air panas dan dipijarkan hingga bobot tetap, kemudian ditimbang. Percobaan dilakukan sebanyak 3 kali. Dihitung kadar abu yang tidak larut dalam asam terhadap bahan yang telah dikeringkan diudara.

\section{Pemeriksaan Ekstrabilitas Serbuk}

a. Penetapan kadar sari yang larut dalam air

Sebanyak 5 gram serbuk daun Anting-anting (Acalypha indica.L) dimaserasi dengan $100 \mathrm{ml}$ air kloroform P (2,5 ml kloroform dalam $1000 \mathrm{ml}$ air) selama 24 jam, menggunakan labu bersumbat kaca, sambil sekali-kali dikocok selama 6 jam, kemudian dibiarkan selama 18 jam. Disaring, kemudian diuapkan $20 \mathrm{ml}$ filtrate hingga kering dalam cawan yang telah dikonstankan, sisa dipanaskan pada suhu $105^{\circ} \mathrm{C}$, lalu ditimbang hingga bobot tetap. Percobaan dilakukan sebanyak 3 kali. Dihitung kadar sari yang larut dalam air terhadap bahan yang telah dikeringkan diudara.

\section{b. Penetapan kadar sari yang larut dalam etanol} Sebanyak 5 gram serbuk dimaserasi dengan $100 \mathrm{ml}$ etanol selama 24 jam, menggunakan labu bersumbat kaca, sambil sekali-kali dikocok selama 6 jam, kemudian dibiarkan selama 18 jam. Disaring, kemudian diuapkan $20 \mathrm{ml}$ filtrat hingga kering dalam cawan yang telah dikonstankan, sisa dipanaskan pada suhu $105^{\circ} \mathrm{C}$, lalu ditimbang hingga bobot tetap. Percobaan dilakukan sebanyak 3 kali. Dihitung kadar sari yang larut dalam etanol terhadap bahan yang telah dikeringkan diudara.

6. Reaksi Identifikasi Kimia Serbuk Daun Anting-Anting (Acalypha indica.L)

a. Reaksi identifikasi terhadap lignin

Serbuk dibasahi dengan larutan fluroglusin LP, ditambah $\mathrm{HCl}$ P, diamati dibawah mikroskop, jika dinding sel yang berlignin akan berwarna merah.

b. Reaksi identifikasi terhadap tanin

1. Reaksi identifikasi terhadap katekol

a. Serbuk ditambah dengan larutan $\mathrm{FeCl}_{3} 1 \mathrm{~N}$, jika mengandung katekol, akan menghasilkan warna hijau.

b. Serbuk ditambah dengan larutan brom, jika mengandung katekol, akan terjadi endapan. 


\section{Reaksi identifikasi terhadap pirogalotanin}

a. Serbuk ditambah dengan larutan $\mathrm{FeCl}_{3} 1 \mathrm{~N}$, jika mengandung pirogalotanin, akan menghasilkan warna biru.

b. Serbuk ditambah dengan larutan brom, jika mengandung pirogalotanin, tidak terjadi endapan.

c. Serbuk ditambahkan $\mathrm{NaOH}$ jika menghasilkan warna merah coklat, berarti mengandung pirogalotanin.

\section{Reaksi identifikasi terhadap dioksiantrakinon}

Serbuk dimasukkan kedalam tabung reaksi, lalu ditetesi dengan $\mathrm{KOH} 10 \%$ b/v dalam etanol $90 \%$ $\mathrm{P}$, jika mengandung dioksiantrakinon akan menghasilkan warna merah.

\section{Reaksi identifikasi terhadap fenol}

a. Serbuk dimasukkan dalam vial, ditambahkan air, lalu ditutup dengan kaca objek, yang diatasnya telah diberi kapas yang telah dibasahi dengan air, kemudian dipanaskan. Setelah ada uap yang berupa cairan pada kaca objek, diambil dan ditambahkan $\mathrm{FeCl}_{3} \mathrm{P}$, jika mengandung fenol akan menghasilkan warna biru hitam.

b. Serbuk dimasukkan dalam tabung reaksi, lalu ditetesi dengan $\mathrm{H}_{2} \mathrm{SO}_{4} \mathrm{P}$ dalam Formalin $1 \%$, jika mengandung Fenol akan menghasilkan cincin warna merah, coklat, jingga, ungu sampai hijau.

\section{Reaksi identifikasi terhadap alkaloid}

Dimasukkan ekstrak etanol daun Antinganting (Acalypha indica.L) ke dalam masing-masing tabung reaksi, kemudian ditetesi :

a. $\mathrm{HCl} 0,5 \mathrm{~N}$ dan pereaksi Mayer, jika mengandung alkaloid maka akan menghasilkan endapan putih.

b. $\mathrm{HCl} 0,5 \mathrm{~N}$ dan pereaksi Bauchardat, jika mengandung alkaloid maka akan menghasilkan endapan coklat.

c. $\mathrm{HCl} 0,5 \mathrm{~N}$ dan pereaksi Dragendroff, jika mengandung alkaloid maka akan menghasilkan endapan berwarna jingga.

\section{Reaksi identifikasi karbohidrat}

Serbuk dikocok dalam air, lalu dimasukkan dalam tabung reaksi kemudian ditetesi :

a. Pereaksi Molish, jika mengandung karbohidrat akan menghasilkan cincin ungu.

b. Pereaksi Luff, jika mengandung karbohidrat akan menghasilkan endapan merah.

c. Pereaksi Fehling A dan Fehling B, jika mengandung karbohidrat akan menghasilkan endapan kuning jingga.

7. Reaksi identifikasi terhadap pati dan aleuron

a. Serbuk di tempatkan diatas kaca objek, kemudian ditetesi dengan larutan Iodine 0,1 $\mathrm{N}$, jika mengandung pati akan berwarna biru, dan warna kuning coklat sampai coklat jika mengandung aleuron.

b. Serbuk dimasukkan kedalam tabung reaksi lalu ditetesi dengan pereaksi Luff dan dipanaskan, jika mengandung pati akan menghasilkan endapan merah bata.

\section{Reaksi identifikasi terhadap steroid}

Ekstrak eter dimasukkan kedalam tabung reaksi, kemudian ditetesi pereaksi Lieberman Baurchardat, jika mengandung steroid akan berwarna biru sampai hijau.

\section{Reaksi identifikasi terhadap saponin}

Serbuk dimasukkan dalam tabung reaksi, tambahkan $10 \mathrm{ml}$ air panas, dinginkan kemudian kocok kuat-kuat selama 10 detik, terbentuk buih, lalu ditambahkan 1 tetes asam klorida $2 \mathrm{~N}$, buih tidak hilang.

\section{Reaksi identifikasi terhadap flavonoid}

Sampel dimasukkan dalam tabung reaksi lalu ditambahkan $\mathrm{FeCl}_{3}$ lalu ditambahkan $\mathrm{HCl}$, jika terbentuk warna merah keunguan berarti menunjukan adanya flavanoid.

\section{HASIL DAN PEMBAHASAN}

Anting-anting (Acalypha indica L.) termasuk dalam tumbuhan herba semusim, tegak berambut, tumbuh dengan tinggi $30-50 \mathrm{~cm}$. Tumbuh di pinggir jalan, lapangan rumput, dan lereng gunung. Batangnya berbentuk bulat berkayu, dengan permukaan yang licin berambut, jenis batangnya basah, arah tumbuh batang tegak dengan warna hijau pada bagian luar dan agak keputihan pada bagian dalamnya. Anting-anting (Acalypha indica L.) memiliki daun tunggal, dengan bentuk daun bulat lonjong, ujung meruncing dan pangkalnya tumpul, tepi daun bergerigi, permukaan daunnya licin suram, daging daun tipis lunak bertulang menyirip dimana ibu tulang daunnya dari pangkal ke ujung, berwarna hijau dengan panjang 2,5 cm. Memiliki akar tunggang yang bercabang, yang memiliki akar khusus penunjang. Berbentuk bulat dengan permukaan yang agak kasar, dan memiliki banyak cabang akar hingga serabut akar dan berwarna putih kekuningan (Yuniarti,2008).

Dalam penelitian ini digunakan Daun Anting-anting (Acalypha indica L.) karena Antinganting digunakan oleh masyarakat luas sebagai obat disentri, diare, gangguan pencernaan, muntah darah, berak darah dan kencing darah, khususnya pada daun berkhasiat mengobati mimisan (Hariana,2005). Selain itu telah dilakukan beberapa penelitian bahwa Anting - anting (Acalypha indica L.) mempunyai efek hipoglikemik terhadap mencit (Mus musculus) serta sifat kimiawi dan efek farmakologis dari tumbuhan Anting-anting adalah rasa pahit, antibiotik, antiradang, peluruh seni, astringent, menghentikan 
pendarahan (hemostatik) (Yuniarti, 2008 : Safriani.R, 2007) . Untuk pemeriksaan morfologi, organoleptik dan anatomi diambil bagian tumbuhan berupa akar, batang dan daun dengan cara diambil bagian tumbuhan yang masih segar, dilakukan pengamatan, sedangkan pemeriksaan ekstrabilitas, tetapan fisis, identifikasi kandungan kimia bagian tumbuhan yang diambil ialah daun.
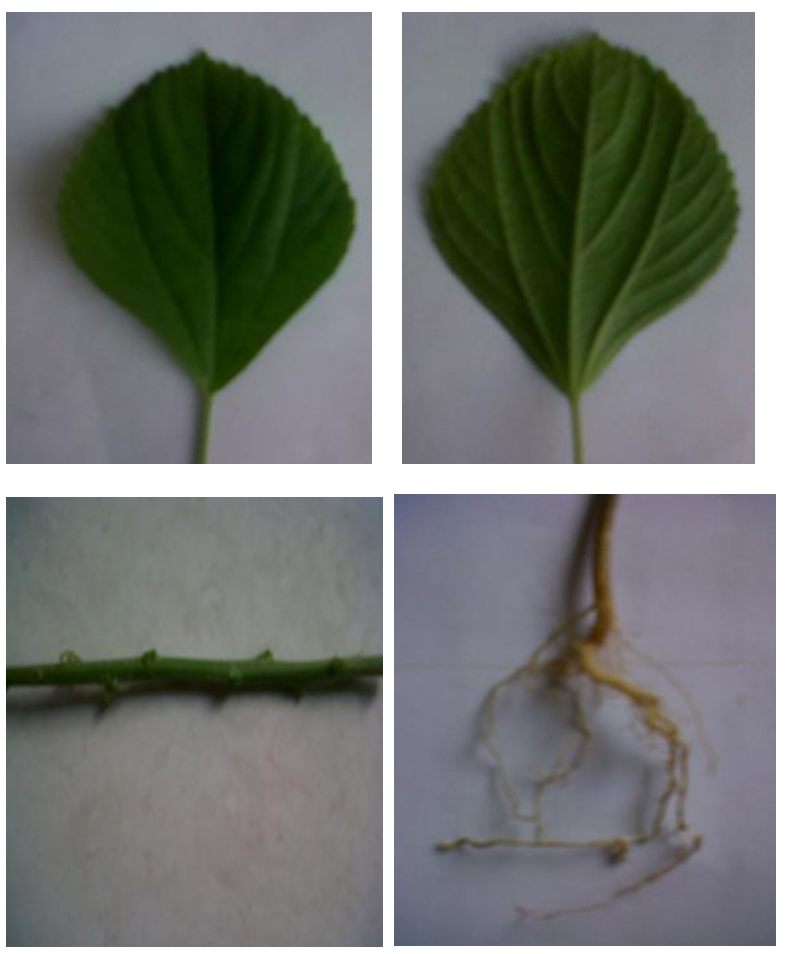

Gambar 1. Bagian-bagian Tumbuhan Anting-anting (Acalypha indica L.)

Keterangan :

1. Daun tampak Depan (Folium)

2. Daun tampak Belakang (Folium)

3. Batang (Caulis)

4. Akar (Radix)

Dalam pemeriksaan identitas tumbuhan Anting anting (Acalypha indica L.) dilakukan beberapa pengamatan seperti morfologi, anatomi dan organoleptik. Pengamatan morfologi dilakukan dengan mengamati bentuk fisik dari simplisia yakni ukuran, warna dan bentuk simplisia dan juga merupakan salah satu cara dalam memperkenalkan tanaman karena mengingat tanaman yang sama belum tentu mempunyai bentuk morfologi yang sama pula. Dari penelitian menunjukan bahwa tumbuhan Anting-anting (Acalypha indica L.) merupakan salah satu tumbuhan herba semusim yang mengeluarkan aroma khas, dengan tinggi $30 \mathrm{~cm}$, bulat (teres), bercabang dan tumbuh ke atas, daun bulat lonjong (orbicularis), tepi bergerigi (serratus). Merupakan daun tunggal bertangkai pendek, dengan bentuk daun bulat lonjong (orbicularis), ujung (apex) meruncing (acuminatus) dan pangkalnya (basis) tumpul (obtusus), tepi daun ( margo folii) bergerigi (serratus), permukaan daunnya licin (laevis), suram (opacus), daging daun (Intervenium) tipis lunak (herbaceus), bertulang menyirip (penninervis) dimana ibu tulang daunnya dari pangkal (basis) ke ujung (apex), berwarna hijau dengan panjang $2,5 \mathrm{~cm}$. Batangnya berbentuk bulat (teres), berkayu (lignosus), dengan permukaan yang licin berambut (Laevis), jenis batangnya basah (Herbaceus), arah tumbuh batang tegak (fastigiatus) dengan warna hijau pada bagian luar dan agak keputihan pada bagian dalamnya. Merupakan akar tunggang yang bercabang (ramosus), yang memiliki akar khusus penunjang. Berbentuk bulat (teres) dengan permukaan yang agak kasar, dan memiliki banyak cabang akar (radix lateralis) hingga serabut akar (fibrilla radicalis) dan berwarna putih kekuningan.

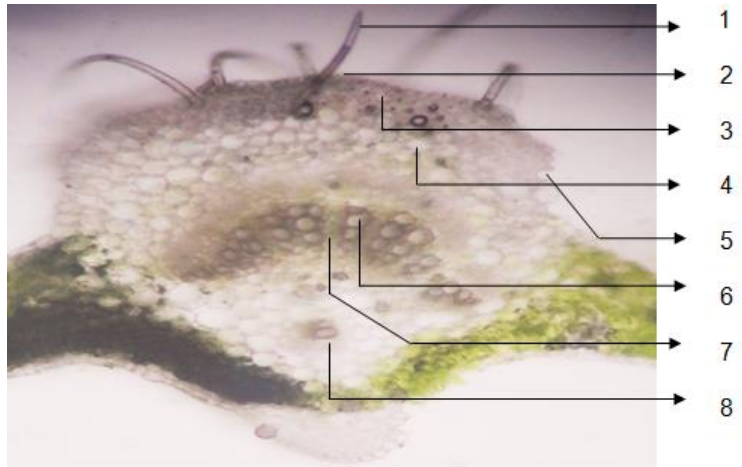

Gambar 2. Foto penampang melintang daun Anting-anting (Acalypha indica L.) pembesaran 10x. Keterangan :

1. Trikoma

2. Kutikula

3. Epidermis

4. Palisade

5. Jaringan bunga karang

6. Xylem

7. Floem

8. Kolenkim

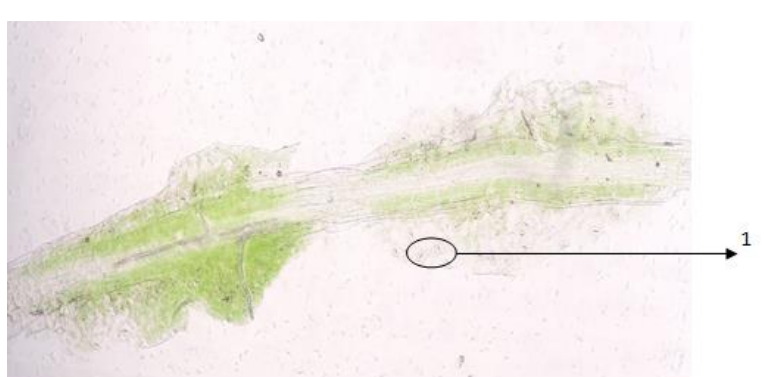

Gambar 3. Foto penampang membujur daun Anting-anting (Acalypha indica L.) pembesaran $10 \mathrm{x}$ 


\section{Keterangan :}

1. Tipe stomata anisositik

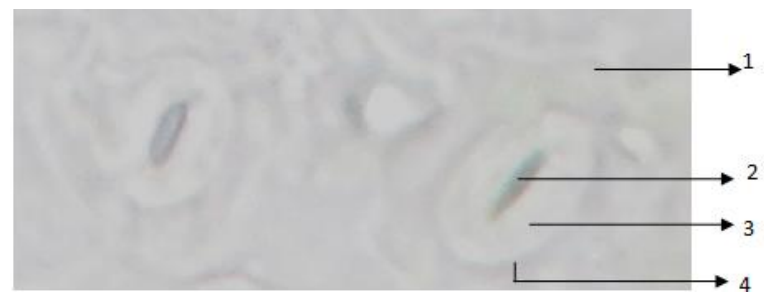

Gambar 4. Foto Tipe Stomata Anisositik daun Anting-anting (Acalypha indica L.) pembesaran 40x Keterangan :

1. Sel pelindung

2. Celah stomata

3. Sel pembuka

4. Sel penutup

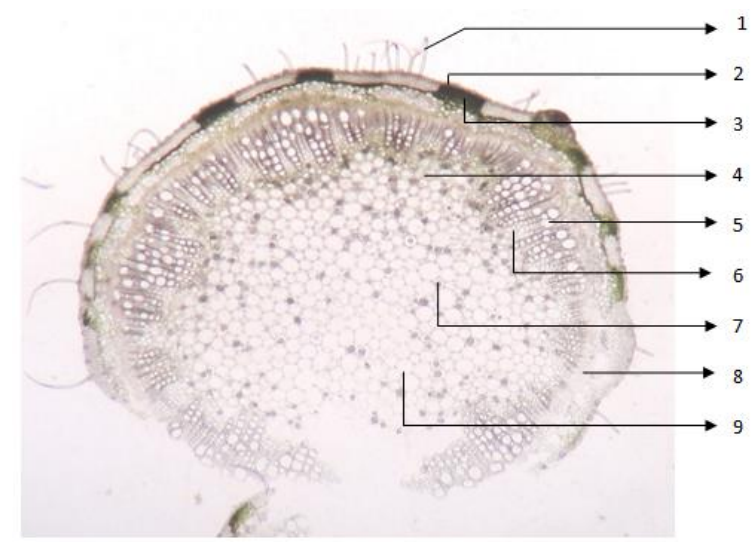

Gambar 5. Foto penampang melintang Batang Anting-anting (Acalypha indica L.) pembesaran 10x

Keterangan :

1. Rambut Penutup (Trikoma)

2. Kutikula

3. Epidermis

4. Parenkim Korteks

5. Xylem

6. Floem

7. Hablur Ca-oksalat

8. Serabut Sklerenkim

9. Empulur

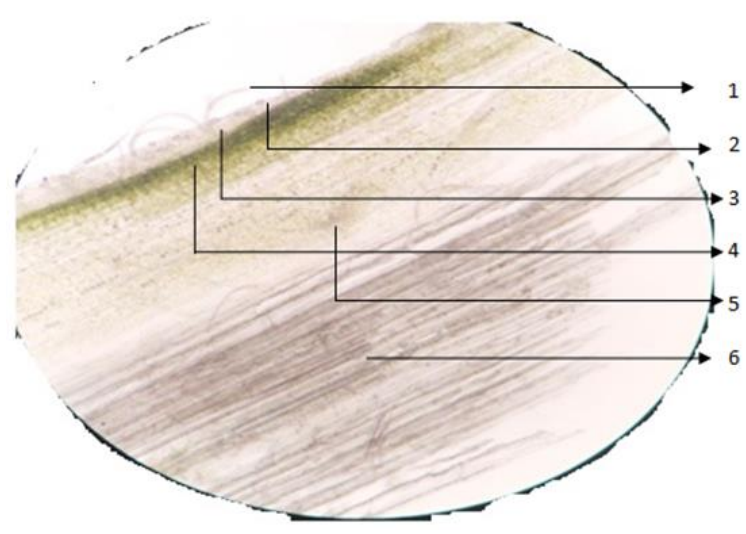

Gambar 6. Foto penampang membujur Batang Anting-anting (Acalypha indica L.) pembesaran 10x. Keterangan :

1. Rambut Penutup

2. Kutikula

3. Epidermis

4. Sklerenkim

5. Parenkim

6. Berkas pembuluh

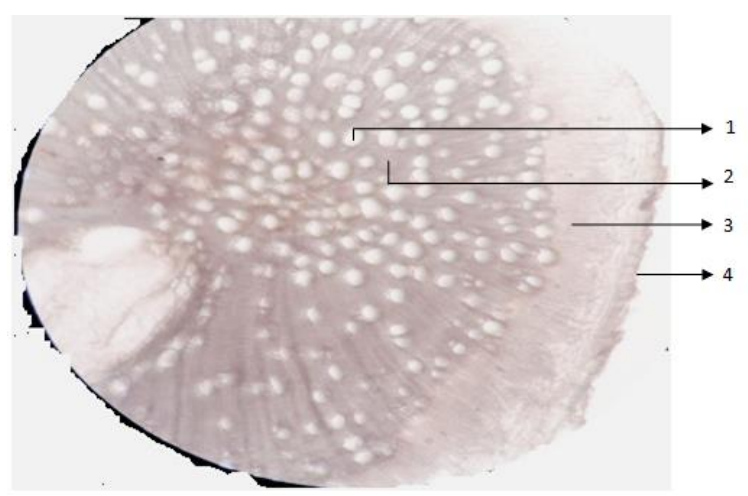

Gambar 7. Foto penampang melintang Akar Anting-anting (Acalypha indica L.) pembesaran 10x Keterangan :

1. Xylem

2. Floem

3. Epidermis

4. Parenkim korteks 


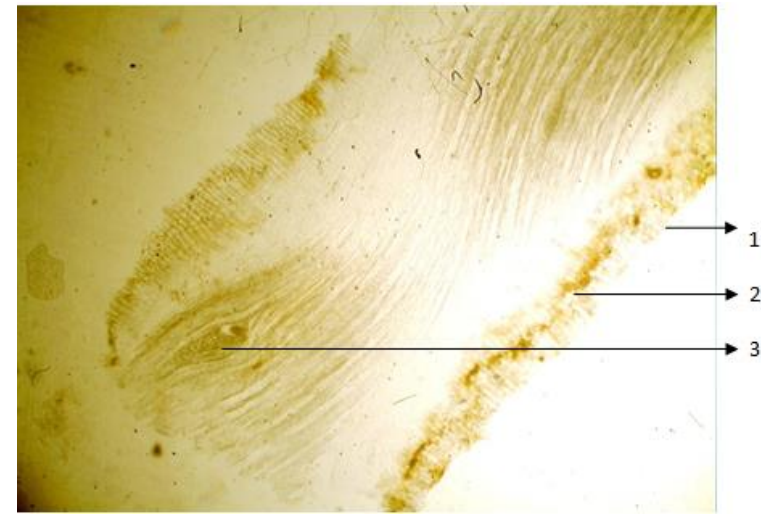

Gambar 8. Foto penampang membujur Akar Antinganting (Acalypha indica L.) pembesaran 10x.

\section{Keterangan :}

1. Epidermis

2. Parenkim korteks

3. Berkas pembuluh

Pengamatan anatomi dilakukan untuk mengamati bentuk sel dan jaringan, yang diuji berupa sayatan melintang dan membujur dari sampel tumbuhan, dilakukan dengan menggunakan mikroskop yang derajat pembesarannya disesuaikan dengan keperluan. Dari hasil penilitian diperoleh data pada penampang melintang daun Anting-anting (Acalypha indica L.) pembesaran 10X terdapat trikoma, kutikula, epidermis, palisade, jaringan bunga karang, xylem, floem dan kolenkim. Pada jaringan parenkim (mesofil) yang berkedudukan diantara epidermis daun bagian atas dan bawah ada dua daerah yang dapat dibedakan : bagian atas, parenkim palisade (jaringan pagar) terdiri dari sel-sel memanjang, dan bagian bawah parenkim spongiosa (jaringan bunga karang) terdiri atas sel-sel dengan bentuk yang tidak teratur dengan ruang antar sel yang luas. Parenkim palisade paling banyak dipadati dengan kloroplas. Pada epidermis didapati stomata yang berfungsi untuk pertukaran gas antar jaringan daun dan atmosfir (Fahn, 1995), dan stomata terlihat pada penampang membujur daun Anting-anting (Acalypha indica L.) pembesaran 10x terdapat tipe stomata anisositik, untuk pembesaran 40x terdapat sel pelindung, bukaan stomata, dinding dalam dan sel epidermal. Pada penampang melintang batang Anting-anting (Acalypha indica L.) pembesaran 10x terdapat trikoma, parenkim korteks, kutikula, epidermis, xylem, floem, hablur Ca-oksalat, serabut sklerenkim, dan empulur. Sedangkan pada penampang membujur batang Anting-anting (Acalypha indica L.) pembesaran 10x terdapat rambut penutup (trikoma), kutikula, epidermis, parenkim, berkas pembuluh dan sklerenkim. Pada penampang melintang akar Anting-anting (Acalypha indica L.) pembesaran 10x terdapat xylem, floem, parenkim korteks dan epidermis. Sedangkan pada penampang membujur akar Anting-anting (Acalypha indica L.) pembesaran 10x terdapat berkas pembuluh, parenkim korteks dan epidermis.

Tabel 1. Hasil pemeriksaan organoleptik tumbuhan Anting-anting (Acalypha indica L.)

\begin{tabular}{|l|l|l|l|l|}
\hline No & Pemeriksaan & Warna & Rasa & Bau \\
\hline 1 & Daun & Hijau & Pahit & Khas \\
\hline 2 & Batang & Hijau kecoklatan & Tidak berasa & Khas \\
\hline 3 & Akar & Putih kekuningan & Tidak berasa & Khas \\
\hline
\end{tabular}

Pengamatan organoleptik tanaman dimaksudkan untuk mengetahui sifat-sifat fisik yang khas dari tanaman tersebut dengan melakukan pengamatan terhadap bentuk, warna, bau dan rasa dari suatu tanaman yang merupakan pengenalan awal yang sederhana dan subjektif (DepKes, 1987.,2000). Dari hasil pengamatan yang diperoleh maka sifat organoleptik dari tumbuhan Anting-anting (Acalypha indica L.) adalah Daun berwarna hijau, rasa pahit dan berbau khas. Batang berwarna hijau kecoklatan, tidak berasa dan berbau khas. Akar berwarna putih kekuningan, tidak berasa dan berbau khas. Berdasarkan hal tersebut, maka dilakukan dua parameter standar mutu tumbuhan Anting-anting (Acalypha indica L.) meliputi parameter non spesifik yaitu kadar abu total, dan kadar abu tidak larut asam. Sedangkan parameter standar mutu spesifik yaitu identitas tumbuhan (morfologi, anatomi, organoleptik), kadar sari larut air, kadar sari larut etanol, dan identifikasi kandungan kimia.

Tabel 2. Hasil pemeriksaan tetapan fisis serbuk daun Anting-anting(Acalypha indica L.)

\begin{tabular}{|l|l|l|}
\hline No. & Pemeriksaan & Hasil \\
\hline 1. & Kadar abu total & $16,36 \%$ \\
\hline 2. & Kadar abu tidak larut asam & $5,16 \%$ \\
\hline
\end{tabular}

Tabel 3. Hasil pemeriksaan tetapan ekstrabilitas serbuk daun Anting-anting (Acalypha indica L.)

\begin{tabular}{|l|l|l|}
\hline No. & Pemeriksaan & Hasil \\
\hline 1. & Kadar sari larut dalam air & $25,16 \%$ \\
\hline 2. & Kadar sari larut dalam etanol & $26,36 \%$ \\
\hline
\end{tabular}

Tetapan fisis dari tumbuhan anting-anting (Acalypha indica L.) ini di lakukan berupa penetapan kadar abu total, dan kadar abu tidak larut dalam asam. Pemeriksaan ini bertujuan untuk menentukan besarnya kandungan bahan anorganik yang terdapat pada simplisia tersebut, dan dapat digunakan untuk mengidentifikasi suatu simplisia karena tiap simplisia mempunyai kandungan atau kadar abu yang berbedabeda(Anonim, 2009). Atas dasar tersebut dapat 
ditentukan besarnya cemaran bahan-bahan anorganik yang terdapat dalam simplisia yang terjadi pada saat pengolahan ataupun dalam pengemasan simplisia. Pelarut asam klorida digunakan untuk melarutkan logam-logam organik, sedangkan yang tidak larut dalam asam biasanya mengandung silikat yang berasal dari tanah atau pasir. Berdasarkan penelitian yang dilakukan diperoleh kadar abu total sebesar $16,36 \%$, dan kadar abu yang tidak larut asam sebesar $5,16 \%$. Hal ini tidak sesuai persyaratan kadar abu larut asam simplisia yaitu tidak boleh lebih dari $2 \%$. Kandungan abu total yang tinggi dalam bahan dan produk pangan merupakan indikator yang sangat kuat bahwa produk tersebut potensi bahayanya sangat tinggi untuk dikonsumsi. Tingginya kandungan abu berarti tinggi pula kandungan unsur-unsur logam dalam bahan atau produk pangan (Endra, 2009).

Pengujian kadar sari dilakukan dengan tujuan yaitu agar dapat memberikan gambaran awal jumlah senyawa kandungan dengan cara melarutkan ekstrak sediaan dalam pelarut organik tertentu (etanol/air) (DepKes, 2000). Penetapan kadar sari yang larut dalam air digunakan untuk menentukan kemampuan dari bahan obat tersebut apakah tersari dalam pelarut air dan dapat menjadi acuan penggunaan jamu dalam bentuk rebusan (infusa) oleh masyarakat, sehingga efek yang diinginkan tercapai. Penetapan kadar sari yang larut dalam etanol digunakan untuk mengetahui apakah bahan baku obat tradisional tersebut dapat tersari dalam etanol dan dapat dijadikan dasar dalam pembuatan ekstrak. Berdasarkan penelitian yang telah dilakukan maka diperoleh hasil penetapan kadar sari terhadap serbuk daun Anting-anting (Acalypha indica L.) yaitu kadar sari yang larut dalam air sebesar 25,61\%, dan kadar sari yang larut dalam etanol sebesar $26,36 \%$.

\begin{tabular}{|c|c|c|c|c|c|}
\hline \multirow{2}{*}{ No. } & \multirow{2}{*}{ Uji } & \multirow{2}{*}{ Pereaksi } & \multicolumn{2}{|l|}{ Warna } & \multirow{2}{*}{ Ket. } \\
\hline & & & Pustaka & Hasil & \\
\hline 1. & Lignin & Fluoroglusin $+\mathrm{HCl}$ & Merah & Kuning kecoklatan & - \\
\hline \multirow{3}{*}{2.} & \multirow{3}{*}{$\begin{array}{l}\text { Tanin } \\
\text { a. Katekol } \\
\text { b. Pirogalotanin }\end{array}$} & $\mathrm{FeCl}_{3} 1 \mathrm{~N}$ & Hijau & Kuning kecoklatan & - \\
\hline & & $\mathrm{FeCl}_{3} 1 \mathrm{~N}$ & Biru & Kuning kecoklatan & - \\
\hline & & $\mathrm{NaOH}$ & Kecoklatan & Hijau & - \\
\hline 3. & Dioksiantrakinon & $\mathrm{KOH} 10 \%$ & Merah & Hijau & - \\
\hline 4. & Fenol & $\mathrm{FeCl}_{3}$ & Biru-hitam & Kuning & - \\
\hline 5. & Flavanoid & $\mathrm{FeCl}_{3}+\mathrm{HCl}$ & Merah & Merah & + \\
\hline 6. & Alkaloid & $\begin{array}{l}\mathrm{HCl} \quad 0,5 \\
\text { Dragendrof }\end{array} \quad \mathrm{N} \quad+$ & $\begin{array}{l}\text { Endapan } \\
\text { Jingga } \\
\text { merah }\end{array}$ & terbentuk endapan & + \\
\hline 7. & Steroid & $\begin{array}{l}\text { Lieberman } \\
\text { bauchardad }\end{array} \quad+$ & Biru - Hijau & Hijau & + \\
\hline 8. & Karbohidrat & Luff & $\begin{array}{l}\text { Endapan } \\
\text { Merah }\end{array}$ & Hijau & - \\
\hline 9. & $\begin{array}{l}\text { Aleuron } \\
\text { Pati }\end{array}$ & Iodin $0,1 \mathrm{~N}$ & $\begin{array}{l}\text { Biru (pati) } \\
\text { Kuning } \\
\text { Coklat } \\
\text { (Aleuron) }\end{array}$ & Kuning coklat & $\begin{array}{l}+ \\
\text { Aleuron }\end{array}$ \\
\hline 10. & Saponin & $\mathrm{HCl} 2 \mathrm{~N}$ & $\begin{array}{l}\text { Terbentuk } \\
\text { buih }\end{array}$ & Terbentuk buih & + \\
\hline
\end{tabular}


Identifikasi kandungan kimia simplisia nabati dilakukan dalam bentuk rajangan, serbuk, ekstrak atau dalam bentuk lain yang ditambahkan dengan pereaksi tertentu dan reaksi warna. Metode ini digunakan untuk mengetahui senyawa yang terkandung dalam serbuk daun Anting-anting (Acalypha indica L.). Dari hasil penelitian menunjukkan bahwa senyawa yang terkandung dalam serbuk daun Anting-anting adalah aleuron, steroid, alkaloid, saponin dan flavanoid. Pada literatur daun Anting-anting (Acalypha indica L.) mengandung minyak atsiri, namun pada hasil penelitian tidak terdapat minyak atsiri hal ini kemungkinan disebabkan oleh sedikitnya kandungan minyak atsiri sehingga tidak tampak pada pengujian kandungan kimia yang dilakukan.

\section{KESIMPULAN}

Berdasarkan hasil pemeriksaan farmakognostik serta identifikasi komponen kimia tumbuhan Anting-anting (Acalypha indica L.) dapat ditarik kesimpulan sebagai berikut :

1. Pemeriksaan morfologi menunjukkan bahwa tumbuhan ini merupakan salah satu tumbuhan herba semusim dengan tinggi $30 \mathrm{~cm}$. Daunnya merupakan daun tunggal, bentuk daun bulat lonjong (orbicularis), berwarna hijau. Batangnya berbentuk bulat (teres), berkayu (lignosus). Merupakan akar tunggang yang bercabang (ramosus), berbentuk bulat (teres), berwarna putih kekuningan.

2. Pada penampang membujur daun Anting-anting (Acalypha indica L.) terdapat stomata dengan tipe Anisositik.

3. Identifikasi komponen kimia terhadap serbuk daun Anting-anting (Acalypha indica L.) diperoleh hasil yang positif terhadap Aleuron, steroid, alkaloid, saponin dan flavanoid.

4. Pemeriksaan tetapan fisis serbuk daun Antinganting (Acalypha indica L.) diperoleh kadar abu total $16,36 \%$ dan kadar abu tidak larut asam $5,16 \%$.

5. Pemeriksaan ekstrabilitas serbuk daun Antinganting (Acalypha indica L.) diperoleh kadar sari yang larut dalam air 25,61\% dan kadar sari yang larut dalam etanol $26,36 \%$.

\section{DAFTAR PUSTAKA}

Agoes, Goeswin. 2007. Teknologi Bahan Alam. Institut Teknologi Bandung, Bandung.

Anonim, 2009. Pharmacognosy Applied And Practice. Universitas Muslim Indonesia, Makassar.

Dalimarta,S. 2000. Atlas Tumbuhan Obat Indonesia, jilid 2. Trubus agriwidjaya, Jakarta.
Direktorat Jenderal Pengawasan Obat dan Makanan. 2008. Farmakope Herbal Indonesia Edisi I. Departemen Kesehatan RI, Jakarta.

Direktorat Jenderal Pengawasan Obat dan Makanan. 1979. Farmakope Indonesia. Departemen Kesehatan RI, Jakarta.

Direktorat Jendral Pengawasan Obat dan Makanan. 1987. Analisis Obat Tradisional, Jilid I. Departemen Kesehatan RI, Jakarta.

Direktorat JendraI Pengawasan Obat dan Makanan. 2000. Parameter Standar Umum Ekstrak Tumbuhan Obat. Departemen Kesehatan RI, Jakarta.

Direktorat Jenderal Pengawasan Obat dan Makanan. 1986. Sediaan Galenik. Departemen Kesehatan RI, Jakarta.

Endra, 2009. Penetapan Kadar. (Online), (http://eremjezone.blogspot.com/2010/05/ka dar-abu.html, Diakses 2 Februari 2012).

Fahn, A. 1995. Anatomi Tumbuhan Edisi III. Gajah Mada University Press, Yogyakarta.

Hariana, A. 2005. Tumbuhan Obat Dan Khasiatnya, Seri Agrisehat I, Penebar Swadaya, Jakarta.

Harmita, 2006. Analisis Fisiko Kimia. Departemen Farmasi UI, Jakarta.

Indralaya, 2010. Epidermis Pada Tumbuhan. Universitas Sriwijaya, Palembang.

Irma, 2010. Penetapan Kadar Kandungan Simplisia. (Online), (http://worldofandika.blogspot.com/2010/06 /gravimetri penetapan-kadar-air-dan.html) Diakses, 4 Februari 2012).

ITIS. 1996. Integrated Taxonomic Information System, (Online), (http://wwwtaxonomichierarchy- Acalyphaindica. L) Diakses,6 Juni 2012).

Khopkar, S.M. 2002. Konsep Dasar Kimia Analitik. Universitas Indonesia Press, Jakarta

Safriani, 2007. Uji Hipoglikemik Herba Antinganting (Acalypha australis. LINN) pada Mencit (Mus musculus), Skripsi Fakultas Farmasi Universitas Muslim Indonesia, Makassar.

Saifudin, A. dkk. 2011. Standarisasi Bahan Obat Alam, Edisi pertama. Graha ilmu, Yogyakarta.

Stahl, Egon. 1985. Analisis Obat Secara Kromatografi dan Mikroskop. Institut Tekhnologi Bandung, Bandung.

Sudjadi. 2007. Kimia Farmasi Analisis.PT Pustaka Pelajar, Jogjakarta.

Tjitrosoepomo, G. 2005. Morfologi Tumbuhan, Cetakan kelima belas. Gajah Madah University Press, Yogyakarta.

Yuniarti, T. 2008. Ensiklopedia Tanaman Obat Tradisional. MedPress, Yogyakarta. 